\title{
Multiple Minute Gallbladder Muscle Calcifications
}

Adriana Handra-Luca, MD, $\mathrm{PhD}^{1,2}$

${ }^{1}$ Service d'Anatomie Pathologique, APHP GHU Avicenne, Bobigny, France

2 University Sorbonne Paris Nord, UFR SMBH, Bobigny France

Surg J (NY) 2021;7:e172-e173.
Address for correspondence Adriana Handra-Luca, MD, PhD, Service d'Anatomie Pathologique, APHP GHU Avicenne, Universite Paris Nord Sorbonne Cite; 125 rue Stalingrad, 93009 Bobigny, France (e-mail: adriana.handra-luca@aphp.fr).
We have read with great interest the article of Iqbal et al reporting cases of porcelain gallbladder. ${ }^{1}$ Most reported cases show calcifications when at an extensive stage or of bone metaplasia type. ${ }^{2,3}$ However, other types of calcifications can be detected in the gallbladder wall, for example, intracellular epithelial mucosal calcifications in chronic
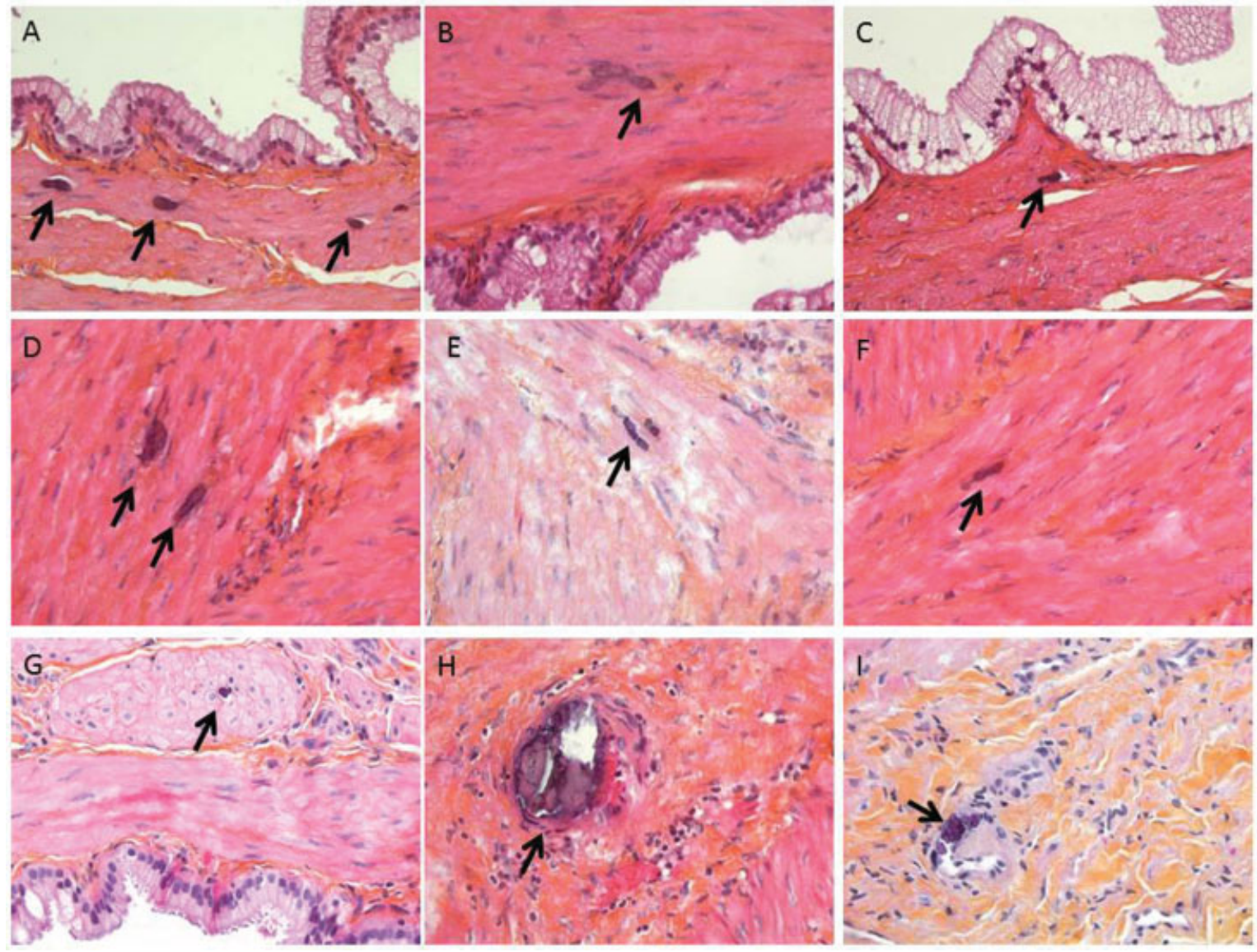

Fig. 1 The calcifications were located at direct contact to the gallbladder muscle (A-F). Some of them were also at contact to the inter-muscle cell connective tissue. Calcifications were also observed at contact to capillary vessel wall (in the muscle layer). To note would be the presence of granular dystrophia of muscle cells (G). Original magnification $\times 40(A-I)$.

received

May 11, 2019

accepted after revision

May 7, 2021
DOI https://doi.org/

$10.1055 / \mathrm{s}-0041-1731449$

ISSN 2378-5128.

\section{(c) 2021. The Author(s).}

This is an open access article published by Thieme under the terms of the Creative Commons Attribution License, permitting unrestricted use, distribution, and reproduction so long as the original work is properly cited. (https://creativecommons.org/licenses/by/4.0/)

Thieme Medical Publishers, Inc., 333 Seventh Avenue, 18th Floor, New York, NY 10001, USA 
cholecystitis. ${ }^{4}$ We would like to draw attention on another type of gallbladder calcifications that of multiple, minute, muscle layer calcifications ( - Fig. 1). Most calcifications were situated between the muscle cells or between muscle cells and the connective tissue (fibrotic or not) of the muscle layer. Some calcifications were situated in zone of muscle granular degeneration/dystrophia and at contact to capillary walls (without calcifications in arteries or veins). The number of reactive lymphocytes was not increased at contact. The gallbladder wall showed mild subacute and chronic cholecystitis.

The histogenesis of this type of extraskeletal calcification is difficult to precise. Renal failure might be incriminated since the medical history revealed increased serum creatinine, cortical right renal cyst in the context of type-2 diabetes diagnosed 5 years previously. Calcifications were detected in the aortic valves, abdominal aorta, iliac and femoral and popliteal arteries, and microcalcifications in the liver (segments 5, 7, and 8), while bone demineralization was diagnosed on computed tomography (CT)-scan. An additive/favoring effect of drugs taken cannot be ruled out, ramipril/hydrochlorothiazide being known to raise serum creatinine, uric acid, as well as calcium and levetiracetam/ parahydroxybenzoate/maltitol, renal failure. ${ }^{5,6}$ Moreover, muscle degeneration was detected at contact of some of the calcifications, possibly result of ischemia as related to the cirrhosis-related vascular changes and to atorvastatine-related muscle abnormalities. ${ }^{7}$
In conclusion, we report multiple, minute gallbladder calcification located in the muscle layer, perivasculary or not. Such lesions of complex etiology and possibly corresponding to an incipient stage of porcelain gallbladder might be of potential clinical relevance for imaging diagnosis.

Conflict of Interest

None declared.

\section{References}

1 Iqbal S, Ahmad S, Saeed U, Al-Dabbagh M. Porcelain gallbladder: often an overlooked entity. Surg J (NY) 2017;3(04):e145-e147

2 Schnelldorfer T. Porcelain gallbladder: a benign process or concern for malignancy? J Gastrointest Surg 2013;17(06):1161-1168

3 Porcelain gallbladder. Accessed April 20, 2019 at: http://knowledge.statpearls.com/chapter/0/27436

4 Albores-Saavedra J, Henson DE, Klimstra D. AFIP atlas of tumor pathology. In: American Registry of Pathology. Tumors of the Gallbladder, Extrahepatic Bile Ducts and Vaterian System Series 4. Vol. 23. Washington, DC: Armed Forces Institute of Pathology; 2015:234

5 https://eurekasante.vidal.fr/medicaments/vidal-famille/medicament-gp2002-COTRIATEC.html August 30th 2018; https://www. vidal.fr/medicaments/cotriatec-5-mg-12-5-mg-cp-151373.html

6 https://eurekasante.vidal.fr/medicaments/vidal-famille/medicament-gp802-KEPPRA.html August 30th 2018; https://www.vidal. fr/medicaments/keppra-1000-mg-cp-pellic-18342.html

7 https://eurekasante.vidal.fr/medicaments/vidal-famille/medicament-gf340007-TAHOR.html August 30th 2018; https://www. vidal.fr/medicaments/tahor-10-mg-cp-pellic-15953.html 